\title{
IRREGULAR MIGRATION AND INTERNATIONAL ECONOMIC ASYMMETRY
}

\author{
Chantal Thomas ${ }^{1}$
}

Forthcoming in World TRADE AND InVESTMENT LAW ReIMAgined: A PROGResSive AgENDA FOR AN INCLUSIVE GlobaliZATION, edited by Alvaro Santos, Chantal Thomas, and David M. Trubek (Anthem Press, 2019).

The world is on the point of a stunning reversal. Nationalism and isolationism have surged against the global laws and institutions that have advanced economic liberalization and integration for half a century. Hostility is rising against international trade and international migration, both of which the new cadre of self-styled "anti-globalists" see as interrelated and threatening to national security and economic stability.

In the case of immigration that is not authorized, this anathema has slipped into a toxic stew of xenophobia and scapegoating, and has fed much of the political and ideological anti-globalist backlash and accompanying orientation towards border militarization that have become increasingly salient in the years since the 2008 global financial crisis. ${ }^{2}$ Those who cross borders without authorization in search of economic opportunity are, within this discourse, portrayed as

morally culpable by virtue of their transgression of national immigration laws, particularly in the global North. Less well-understood are the ways in which international law, itself significantly framed by the governments of the global North, has helped to shape the phenomenon of irregular migration. ${ }^{3}$ This includes the international law of trade, which forms one part of a larger architecture of globalization that over the past quarter-century that brought governments into liberalized arrangements vis-a-vis world markets. 
This chapter examines both the explanatory and the normative implications of the relationship between international trade, and international economic liberalization more generally, and irregular migration. It focuses on a detailed case study of the relationship between Mexico and the United States, in the years leading up to and following the adoption of the North American Free Trade Agreement (NAFTA). While of course characterized by historical specificities, the broad contours of this dynamic pertain in many other instances of undocumented migration from countries in the global South to destinations in the global North.

The argument is the following: increased migration from Mexico to the US, following NAFTA, was a function of (1) increased trade in the context of (2) significant wealth disparity between the two countries coupled with (3) adoption by the Mexican state of neoclassical measures that independently increased economic volatility and prevented the establishment of measures necessary to support both economic growth and stability. International trade liberalization is but one feature of an asymmetric world order that creates pressures for emigration from poor countries to rich countries. The asymmetry in international economic regulation, privileging movement of goods and capital over movement of people, is mirrored by a lack of focus on addressing the effect of international economic shocks on domestic employment. In the explanatory portion (Part 1), I link international economic arrangements to irregular migration flows, and in particular to the asymmetry between people, goods and capital. In the normative portion (Part 2), I argue that this asymmetry must be addressed, and that the way forward is to do so by increasing openness in migration flows, rather than retreating to a more pervasively nationalistic economic model. 
When I first began to develop this analysis, it was intended to unseat the conventional wisdom at that time supporting the status quo embrace of asymmetric economic liberalism in the international order. I sought to show that those shaping the global economic order could not tenably pursue liberalization on some fronts - goods and capital -- but not on others - movement of people. To do so would not prevent the movement of people so much as relegate it, and them, to the informal economy. As I write now, the political winds have shifted dramatically away from the neoclassicism of the status quo ante, in a new and perhaps even more dangerous direction, towards unreconstituted nationalism. The way forward cannot be to retreat from the international economic order, as many in politics currently hold, but rather to remake it to better comply with norms of equity and equality.

\section{Open Markets, Closed Borders: An Asymmetric Globalization}

International trade law was established to coordinate intergovernmental policy and to effectuate the "substantial reduction" of trade barriers. ${ }^{4}$ At the same time that governments established legal institutions like the World Trade Organization and the North American Free Trade Agreement to maximize openness to flows of goods and flows of capital, they resisted enabling the movement of people. The world order designed by international economic law at the end of the $20^{\text {th }}$ century reflected an asymmetrical vision of globalization. It was, to a significant extent, a world vision of "open markets" but "closed borders."

The North American Free Trade Agreement (NAFTA), for example, established requirements to eliminate almost all tariffs on goods traded between Canada, Mexico and the United States, and 
to remove barriers to foreign investment. Yet NAFTA simultaneously excluded almost all labor movement from its purview, making only relatively narrow exceptions to permit some kinds of professional and business visas. The World Trade Organization (WTO) reflected the same imbalance, adopting wide-ranging protocols liberalizing trade in goods and services, but only limited measures on movement of people.

Trade experts have long decried this feature of asymmetry within international economic law, asserting two important critiques. The first critique points out that this asymmetry runs contrary to the logic and theory of economic liberalization. Labor constitutes, along with land and capital, one of the essential "factors of production." As such, the same rationale as to why economic liberalization would increase aggregate social welfare should pertain to it as much as the other two. Yet international institutions pursuing economic liberalization have relaxed national regulatory controls on the ownership and exchange of land and capital (investment reforms and treaties meant that foreign direct investment, capital markets, and land ownership were opened up to foreign actors), while leaving barriers to entry for labor markets largely in place. This internal contradiction, as the law and economics scholars Joel Trachtman and Howard Chang have observed, flouts the logic of free markets and the welfare that they are meant to engender. ${ }^{6}$

The second established critique focuses on the deleterious consequences in particular for developing countries of this asymmetry. Hence the observations by international economists such as Dani Rodrik and Branko Milanovic that cross-border movement, or the lack thereof, constitute the most impactful features of the global economic landscape with respect to the prospects for poverty reduction. Rodrik writes that there "is practically nothing that would do 
more to ... improve[e] the global distribution of income" than to lower "barriers to international labor mobility."7 The continued existence of such barriers constitutes a primary reason why, as Milanovic has shown, global geographical location now forms the single most important factor in determining individual economics prospects. ${ }^{8}$

I offer a third reason why asymmetry is untenable, which centers on irregular migration as an unintended ${ }^{9}$ consequence of broader institutions and policies of liberalization. The governments who crafted international agreements to achieve the liberalization of goods and capital seriously miscast the relationship between these dimensions of economic liberalization and migration patterns, particularly between countries of dramatically different income and poverty levels. In what follows, I present (in Part 1) the empirical case for irregular migration as a consequence of international economic asymmetry, followed by a consideration (in Part 2) of the normative implications of this relationship.

\subsection{Trade and Displacement: The Evidence for a Causal Relationship to Migration}

Around the time that NAFTA's adoption was being debated, one of its extolled virtues was that it would cause a decline, rather than an rise, in Mexico-US migration. Anti-immigration politics were marshaled to build support for NAFTA on the argument that international economic integration between Mexico and the USA would reduce immigration from the former to the latter. ${ }^{10}$ This argument was enabled by a widely accepted economic theorem (the "HeckscherOhlin" theorem), ${ }^{11}$ that trade and migration would act as substitutes between countries that had 
different "factor endowments" - different levels of abundance of the main factors of production (land, labor and capital). With respect to trade between a relatively labor-abundant country and a relatively capital-abundant country, labor-intensive production would move to the former and capital-intensive production would move to the latter. This theorem provided the basis for the argument, circa the adoption of NAFTA, that liberalizing trade between Mexico (the relatively labor-abundant economy) and the United States (the relatively capital-abundant economy) would mean that Mexican workers, instead of crossing the border to look for employment physically inside the US, would stay home and take advantage of increased opportunities to produce goods and services that could be traded with the US. At the same time, the movement of capitalintensive production to the United States would form the basis for the creation of more "goodpaying American jobs," to use the parlance employed by President Clinton in urging the passage of NAFTA. ${ }^{12}$

For this reason, I refer to the Heckscher-Ohlin theorem below as the "substitutionist" line, because it argued that trade and migration acted as substitutes for each other, and therefore that NAFTA would reduce migration by augmenting trade. Even around the time NAFTA was debated, however, migration specialists pointed out that, contrary to the Heckscher-Ohlin model, trade and migration can very well act as complements rather than substitutes. ${ }^{13}$ The substitutionist line depends on a number of assumptions, in particular the assumption that production conditions across the two modeled countries are identical, save for differences in their factor endowments. If other variables are introduced across the countries, such as differences in available production technology, or differences in economies of scale, then trade and migration can complement each other rather than substitute for each other. ${ }^{14}$ 
This latter, anti-substitutionist, prediction more accurately described the movement of Mexican labor into the US that began to be observed not long after NAFTA was implemented, in particular to work in agriculture. The much higher economies of scale and levels of technology of US agribusiness meant that, once lower post-NAFTA tariff prices were factored in, as the University of California agricultural economist Philip Martin put it in 1995, "It turned out that it was cheaper to produce lettuce here [in the United States] using Mexican labor than in Mexico." ${ }^{15}$ Martin continued, "But the perverse effect of that is that it has increased the demand here for Mexican workers [who are willing to do this tough, low-wage work]... We're still sucking in workers to export these commodities." ${ }^{16}$ In other words, the introduction of NAFTA increased both trade and migration across the Mexico-US border. The effect in agriculture was reproduced in numerous other industries, not only in rural sectors but also in urban ones, such as construction and food services.

\subsubsection{Increased Mexico-US Migration, including Irregular Migration, after NAFTA}

A 1995 news report noted that the phenomenon of increased farmworker migration from Mexico to the United States "contradict[ed] the Clinton Administration's claims that Nafta would reduce the floodtide of illegal immigrants." 17 This report acknowledged the fact that much of the labor movement between Mexico and the US to supply farmworkers has been unauthorized. Indeed, in the years since NAFTA's implementation, both regular and irregular migration to the United States increased significantly. From 1994 to 2000, the annual number of Mexican citizens migrating to the US jumped by 79 percent. ${ }^{18}$ A little fewer than half of those were present 
without authorization, with the proportion of irregular migrants climbing to just above half by 2009, when overall net migration from Mexico to the US peaked. ${ }^{19}$

Thus, migration from Mexico to the US more than doubled over the ten years between the mid1990s, when NAFTA entered into force, and the late 2000s when the overall number started to

decline with the global financial crisis. ${ }^{20}$ The estimated number of unauthorized immigrants from Mexico to the US also more than doubled, from 2.9 million in 1995 to 6.9 million in $2007 .{ }^{21}$ Rural migration from Mexico to the US - where much of the farmworker population would come from - grew at two-and-one-half times the rate of the overall increase in Mexico-to-US migration. $^{22}$

\subsubsection{Competing Causal Accounts of the NAFTA-Trade-Migration Relationship}

Although the fact of increased migration from Mexico to the US in the late $20^{\text {th }}$ century and early $21^{\text {st }}$ century is well established, commentators have disagreed on what that fact conveys about the relationship between trade and migration. Critics of NAFTA have argued that increased trade significantly contributed to migration to the US due to the displacement of economic production, especially agricultural production, and the concomitant loss in employment. Those taking a more favorable view have stated NAFTA contributed a net increase to employment, and that the economic situation in Mexico, with its related effects on Mexico-US migration, would have been worse without NAFTA. ${ }^{23}$ On this view, NAFTA, and especially its substitutionist effects, helped to abate, rather than exacerbate, migration from Mexico to the US. 
So where does the truth lie? My argument is that, even if the substitutionist model could theoretically have unfolded, so that NAFTA could in fact potentially have operated to curb migration from Mexico to the US rather than to increase it, the presence of numerous other factors prevented this from happening, and in fact compelled the opposite to happen. Instead, post-NAFTA migration from Mexico to the US grew, as a function of (1) increased trade between the two countries in the context of (2) significant wealth disparity between them, coupled with (3) the adoption by the Mexican state of neoclassical policies that independently increased economic volatility and simultaneously prevented the establishment of measures necessary to support both economic growth and stability.

Rather than coupling trade openness with measures to increase domestic capacity and to offset the immediate effect of trade-related employment losses, the Mexican government both before and after NAFTA hewed to a classically laisser-faire set of policies that reduced its ability to do either. A number of the difficulties arising from increased exposure or vulnerability to the global economy could after all have been remedied at least to some extent with more robust domestic measures. The failure to adopt such measures has been a pervasive feature of the economic status quo, and form the subject of extensive critique throughout the chapters in this volume. Indeed, one can say the same thing about policy in the US, as several chapters in this volume do. The difference is that, given the wage and income differential between Mexico and the US, the absence of domestic opportunity in Mexico contributed to migration flows to the US. As is argued elsewhere in the volume, although international economic law certainly established constraints, it did not require governments, including that of Mexico, to enact the deregulatory 
and de-fiscalizing measures that prevented them from ensuring a more equitable distribution of wealth and income gains in the era of globalization.

\subsection{NAFTA's Aggregate Impact}

An uncontested impact of NAFTA has been to augment the volume of cross-border trade in goods and services between all three partner countries. In the years since NAFTA's implementation, the value of US trade with its NAFTA partners, in terms both of imports and exports, has muliplied five-fold,${ }^{24}$ about twice as quickly as that of the US economy as a whole. ${ }^{25}$ Beyond this observed increase, debates over the benefits of NAFTA have often been quite polemical. A broad swath of literature has concluded that its net effect, apart from the increased total volume of trade is, if anything, hard to characterize ${ }^{26}$ From the US perspective, NAFTA did not deliver on President Clinton's initial (and mistaken) estimate of "a million jobs in the first five years, ${ }^{27}$ or on other NAFTA proponents' forecasts of hundreds of thousands of jobs. ${ }^{28}$ The most positive contemporary assessments conclude that the overall impact of NAFTA for the US has been "small, but positive." 29

Whatever NAFTA's aggregate impact, all assessments of it also agree that it produced concentrated gains and losses for particular sectors. In the US for example, agriculture experienced a boon in its increased exports to Mexico. On the other hand, the US automobile industry experienced significant losses in conjunction with the continental vertical integration of the industry facilitated by NAFTA. ${ }^{30}$ The more critical assessments have contended that autorelated and other manufacturing job losses produced a net loss of 200,000 US jobs in the first 
five years. ${ }^{31}$ (Notwithstanding the notable reorganization of auto and other manufacturing after NAFTA, much of the literature also observed that US deindustrialization was already well under way by the time NAFTA was established. ${ }^{32}$ Since NAFTA was established, deindustrialization has most likely been determined more significantly by a number of other developments, including both the phenomenon of automation, and the phenomenon of broader globalization featuring the rise of many emerging economies in international trade, especially China, with this phenomenon in turn significantly facilitated by the World Trade Organization. ${ }^{33}$ )

The Mexican side of this picture reflected to some extent a mirror image: exports from Mexico to the US in the auto industry grew $480 \%,{ }^{34}$ at the same time that US corn displaced a significant amount of local agricultural production. If US critics of NAFTA saw the agreement as a giveaway to Mexico, that would create a "giant sucking sound" as US jobs fled south of the border, however, the net effect of NAFTA on Mexican employment and economic growth has been just as equivocal as on the US. Mexico’s economy has remained fairly flat in the decades since NAFTA's implementation, showing an annual average growth rate of 0.9 percent - lower than the average rate of the US economy, and particularly low for a developing country. ${ }^{35}$ The failure of the Mexican economy to take off post-NAFTA constitutes one of the factors contributing to the increase of migration to the US.

\subsubsection{Why NAFTA Job Growth Did Not Reduce Mexico-US Migration}

For NAFTA to have performed the function predicted by the Heckscher-Ohlin substitutionist theorem, increased trade would have had to accompany an increase in economic production in 
Mexico, which would in turn have absorbed workers who might otherwise have migrated to the United States. The problem with this scenario, however, is that, in reality, post-NAFTA Mexico saw a net loss of jobs. As indicated above, overall economic production remained flat over the medium term. A further disaggregation shows that agricultural job losses outweighed job gains in manufacturing, with the latter constrained by both productivity increases and by the revolvingdoor nature of much of the new manufacturing work. Between 1994 and 2002, for example, although the manufacturing sector gained 500,000 jobs, the agricultural sector lost 1.6 million jobs, as agriculture reconsolidated into large-scale production. ${ }^{36}$

Within manufacturing, employment gains arose primarily in the maquila sector, whereas nonmaquila manufacturing had actually experienced an overall decline by the early 2000s. Moreover, employment in auto manufacturing did not greatly increase. ${ }^{37}$ The concentration of jobs in the maquila sector helps to account for why job growth in the auto sector lagged even as Mexico's auto exports to the US were increasing robustly. The vertical integration of North American manufacturing meant that many exports were produced through relatively minimal assembly work on imported parts. ${ }^{38}$ As a consequence, a lot of the export value had been created before the products in question reached the Mexican manufacturing stage.

If NAFTA did not create an employment boom that diverted workers from seeking migration to the US, the standard trade economics line would hold that it still likely performed a substitution function, by ensuring that the migration rate was less at least less than it otherwise would have been. In other words, perhaps NAFTA did not decrease migration in absolute terms, but rather in 
relative terms. Under this theory, the substitution effect still held, even if not as significantly as what might have been predicted.

The problem with this scenario is that migration, as indicated above, did not decrease after NAFTA was established, but rather increased, and significantly. In the first ten years after NAFTA was established, migration from Mexico to the US increased by $100 \%$. What then caused the spike in migration, if it was not increased economic liberalization? In order to preserve the substitutionist theorem, alternate explanations have to show why migration increased, rather than decreased, as trade was increasing.

Two such explanations are typically proffered. ${ }^{39}$ The first is that Mexico-US migration, and even the post-NAFTA migration spike, was a function of a generational population boom in Mexico that overwhelmed any contemporaneous substitution effect. The second is that, particularly in the years after NAFTA was adopted, a currency crisis, rather than increased economic liberalization generally, inflicted a dramatic economic contraction and so propelled mass emigration. The two arguments here for alternate causes are explored, and ultimately rejected, below.

\subsubsection{Why Population Growth Does Not Account for the Post-NAFTA Migration Increase}

The aforementioned post-NAFTA increase in migration marked the tail end of "one of the largest mass migrations in modern history," in which the number of Mexican citizens present in the US grew from fewer than 1 million in 1970 to the peak of 12.8 million in $2007 .{ }^{40}$ High population growth rates created a "demographic bulge in the workforce through the late 1990s." 
have argued, as a consequence, that population growth formed the primary cause of increased Mexico-US migration, including after NAFTA.

However, though population growth in Mexico likely fueled some of this migration, that factor alone does not seem to be able to account for all of it. If the population boom were the primary driver behind migration, rather than another factor, one would expect that Mexico-US migration would have increased at roughly the same rate as the population increased, i.e. by fifteen or twenty percent. Instead, migration increased at a much higher and more rapid rate than did the population. Between 1995 and 2005, migration from Mexico to the US increased by $100 \%$. During the same time frame, Mexico's population grew by about $15 \%$, a rate of less than onesixth the migration rate. ${ }^{42}$ Similarly, the working-age population increased by $20 \%$, or about onefifth as quickly as Mexico-US migration. ${ }^{43}$

One way of accounting for this differential rate to preserve the population boom thesis would be to argue that, once the Mexican economy's labor demand was fulfilled, a much higher percentage of "excess" workers traveled across the border. However, this "runoff" theory still does not explain why the rate of excess jumped so quickly after the adoption of NAFTA, and varied so sharply in the pre-NAFTA and post-NAFTA eras. Moreover, the runoff theory cannot support the substitutionist line, which would predict that cross-border migration would decrease, because increased export-oriented jobs would result from opening trade. If any part of the substitutionist line held, the migration rate should have decreased after NAFTA, relative to the general population, rather than increased. Instead, it increased, and much more rapidly than the overall population. In other words, if NAFTA had succeeded in performing the trade-migration 
substitution effect, one would have expected to see the migration rate slow after NAFTA. Instead, migration increased by a much higher percentage than did the population.

\subsubsection{Why the Peso Crisis Does Not Account for the Post-NAFTA Migration Increase}

The Mexican economy experienced a severe shock in 1994-1995 with the peso crisis. The severe contraction of the economy may well have contributed to an increase in emigration, much as had occurred following the 1982 debt crisis. One might argue that this, rather than Mexico-US trade and increased economic liberalization more generally, caused increased emigration. In other words, but for the peso crisis, NAFTA would have performed the intended effect of substituting trade for migration.

The problem with this is that, theoretically, the severe decline in the value of the peso, while disastrous for domestic consumption and demand, should have helped Mexico's export sector. The depreciation of domestic currency should have made Mexican products exports more competitive. Rather than increasing emigration, the peso crisis should have correlated with a decrease in migration as workers were diverted to local production for export, amplifying the trade-migration substitution effect. In other words, the peso crisis as a cause of emigration is not consistent with standard trade economics.

Nor, apparently, is it consistent with the available data. A US International Trade Commission study found that the peso devaluation did boost Mexican exports more than NAFTA-related tariff changes on their own would have. ${ }^{44}$ And, overall, employment in the maquiladoras, an 
indicator of export-oriented production, did add about 500,000 jobs between 1994 and 1999, consistently with this theory, although that number has since declined. ${ }^{45}$ In other words, the effect of the peso crisis did improve export-oriented trade and increase employment in Mexican export-oriented sectors, although this did not appear noticeably to decrease migration rates. In any case, the effect runs counter to the substitutionist argument that the peso crisis could form an alternate explanation for increased emigration from Mexico, since it instead operated to reduce, rather than increase, emigration.

One might contend that, even if export increases due to the peso crisis performed some substitution effect, they could not compensate for the larger drop in demand brought about by the domestic contraction. This contraction would have reduced domestic employment more than any export-related increases could offset, and in that way contributed to increased emigration. The data partially bear out this theory, but only to a very limited extent that does not change the overall picture. The peso crisis period did coincide with a temporary drop in domestic manufacturing: after 1994, non-maquiladora manufacturing did decline. However, by 1997 this decline had reversed itself and by 1998 the domestic industry had recovered the jobs lost (though by 2003 aggregate employment had declined again to below 1998 levels). ${ }^{46}$ Whatever the impact of the peso crisis on domestic demand and production, the isolated effect appears to have been relatively short-lived and overtaken by other dynamics.

Overall, these facts suggest that the failure of the Mexican economy to realize the gains from trade, and concomitantly the phenomenon of increased emigration from Mexico after NAFTA, cannot be attributed to the effect of the peso crisis. Instead, I would argue, these developments 
are consistent with the theory I presented at the outset. The introduction of economic liberalization between countries of such a dramatic wealth disparity as that of the US, coupled with the absence of domestic measures by the Mexican state that would have helped to capture greater gains from this liberalization, contributed to a large outmigration as Mexican citizens sought opportunities elsewhere, and especially in their trading partner to the north.

\subsubsection{Disaggregating Post-NAFTA Mexico-US Migration}

If, contrary to the substitutionist line, displacement resulting from NAFTA helped to contribute to increased migration, one would have expected to see an increase in rural migration since one of the largest immediate effects of NAFTA was a large increase in US agricultural imports to Mexico and a concomitant displacement of Mexican agricultural production. In fact, that is precisely what happened. Rural migration to the US more than tripled between 1995 and 2002, increasing much more quickly than the overall migration rate. ${ }^{47}$

Disaggregating the broad increase in migration from Mexico to the US into component dynamics reveals a number of other trends, all consistent both with rural displacement through losses in the agriculture sector, and with the relative shift in manufacturing from previous centers in Mexico to the border maquila-heavy region. For example, during this same time frame, not only international but also internal migration within Mexico increased, reflecting people's movement from rural areas to urban areas as livelihood opportunities in rural areas collapsed, in part due to competition with US agriculture, but also part of a broader trend towards urbanization. ${ }^{48}$ Whereas in previous eras (most notably during the era of the Bracero Program in the mid- $20^{\text {th }}$ 
century), most migration to the US had come primarily from the rural areas, in the late $20^{\text {th }}$ century migration from urban areas, and particularly from Mexico City and surrounding environs began to increase. ${ }^{49}$ Though the majority of Mexico-US migration still originates in rural areas, a growing proportion of migrants now originate from urban areas. ${ }^{50}$ From 1995 to 2010 , the greatest internal migration flows were to areas outside Mexico City, then to border cities (Tijuana, Ciudad Juarez), and then cities with high growth rates such as Cancun. ${ }^{51}$

Studies have found that about one-quarter of those emigrating from urban areas to the US had previously migrated internally, typically from a rural area. ${ }^{52}$ Most emigrants to the US who were starting out from urban areas, but who had been born there rather than having come from another domestic region, migrated directly to the US; however about one-quarter first migrated internally before crossing the US border, usually to a northern border region, where employment opportunities in the maquila industry would have been more prevalent. ${ }^{53}$ Consequently, the border cities have become an increasingly an important locus for migration, serving as both a home base and final destination for internal migrants, and a staging ground for "career migrants" who move back and forth across the border. ${ }^{54}$

Additionally, however, one saw a marked fragmentation and diversification of livelihood strategies within individual households. In many cases, within a household some local agricultural work would be added to some non-agricultural labor in rural areas largely in the informal sector, which would in turn be added to remittances received by household members both in Mexican cities and across the border. Increasingly, internal migration to cities or to the 
northern border and the maquilas also served as a basis for eventual migration to the US. Overall, what this has meant is that undocumented Mexico-US migration has in the late $20^{\text {th }}$ and early $21^{\text {st }}$ century has taken on the following dimensions. First, and most well established has been the movement of primarily undocumented agricultural workers from the rural areas of central western Mexico and moving directly to the US. Second, and more recent, has been the movement of workers from urban interior communities to the US (some of whom have already migrated internally from rural areas). Thirdly, the northern border region serves as a site for circular migration to the US. ${ }^{55}$ In addition to their geographical dimensions, these migration patterns can also be broken out into their temporal aspects, with some migration more or less permanent in nature, some temporary and based on seasonal work, and some shaped by a "transnational" orientation, in which "immigrants forge and sustain simultaneous multi-stranded social relations that link together their societies of origin and settlement." ${ }^{56}$

\section{Looking Forward: To Close Markets or to Open Borders?}

It is worth stopping here to consider the political subtext of the "asymmetry as causation" argument. One of the concerns with explicitly linking trade and irregular migration is that it will exacerbate and feed into xenophobic tendencies, which have exposed themselves to a startling degree in current political discourse. Trade agreements would be opposed for xenophobic reasons, that is, because they would lead to increased migration from the trade counterparty. This is very strenuously not the intended effect of this analysis. Rather, the intention is the opposite - not to feed into xenophobia but to challenge it. Xenophobic tendencies form a good part of what have 
kept migration issues off the table in these agreements, and that egalitarian principles demand that powerful governments that have initiated these agreements - such as the U.S. in seeking NAFTA in the example above, as well as in supporting international economic regimes of liberalization more generally - should not believe they can have the proverbial cake and eat it too. The putative belief of powerful governments that they can cherry-pick agreements to privilege areas of interest, such as goods and capital, and ignore others, such as migration, will, according to this argument, turn out to be unsustainable. ${ }^{57}$

So what is to be done? How might we imagine counteracting international economic asymmetry? Imagining possibilities for an alternate status quo requires a rather optimistic suspension of belief regarding the possibilities permitted by political will. The most radical measure would be to open up freedom of movement altogether - to have open trade and open borders. This would be most consistent with trade theory and arguably with liberal commitments.

The obvious hard constraint for "open trade/open borders" is politics, and in the current climate that includes clearly a very nasty strain of politics that we can cast in very harsh terms. It also includes, however, an aspect that may be harder to dismiss, and that is related to legitimate claims of citizenship, that is, of belonging and social membership, in which membership necessarily defined both by who is included and who is excluded (see, e.g., Walzer). Either way, politics is a major roadblock to open trade/open borders, and Brexit is of course one of many cautionary tales that could be invoked. 
In light of this, a more piecemeal and modest approach would be to subject migration to GATTstyle sector-by-sector reciprocal negotiations over time. The argument would be that over a period of years this would allow for some momentum. One clear success story is the post-World War II reduction in tariffs, to the point that the weighted average is now for OECD countries under 5\%.

A version of this was at some point proposed in the WTO Doha Development Agenda negotiations by India and some others. Dubbed the "GATS visa," this was a bid to multilateralize temporary work visas that would accompany short-term labor migration (so it would be available for persons covered by sectoral Mode 4 commitments and horizontal commitments of a WTO member under the General Agreement on Trade in Services (GATS)). Ideally the GATS visa would not only facilitate entry but also harmonize immigration and visa procedures, which obviously vary wildly across countries, and perhaps also set out some harmonized rules for wage parity conditions for hiring, work qualifications.

The GATS visa however didn't go anywhere, again running into the problem of political will, since even piecemeal negotiations require some parity or reciprocity of interests from the other side. Moreover, even if the GATS visa could be successful implemented, it would be far from an ideal labor regime. Temporary visas are subject to their own problems with respect to exacerbating vulnerability and precarity in labor through structural features such as non-portability. Typically, employees are tied to one employer, which hugely increases the power of the employer relative to the employee. This is particularly for low skill sectors but there are widespread complaints of exploitation across the board, including for example high skilled information technology workers 
in Silicon Valley. Additionally, competition to get temporary work visas has led to abuses such as debt bondage and other forms of human trafficking, again particularly in low wage sectors.

Another version of the piecemeal approach would be stand-alone bilateral agreements, such as the array of existing Bilateral Labor and Migration Agreements. Again, political will and power differential make it more difficult for these agreements to set out and enforce standards for worker protection, as has been noted by a number of commentators.

One could therefore ditch the piecemeal approach and go back to a more comprehensive solution, but one that extended beyond the economistic analysis of migration towards a recognition of the full implications of labor migration not just for economic production, but for political and social citizenship. In some ways the current effort by the UN General Assembly to establish a Global Compact on Migration, following the call by the 2016 New York Declaration on Refugees and Migrants for a "safe, orderly and comprehensive" approach to migration, seeks to do just that. The US has already pulled out of the talks, of course, and the Global Compact runs the risk of the UN Convention on the Rights of Migrant Workers and Their Families, which has languished at thirtyplus signatories. The UN Migrant Workers Convention at least has entered into force as a treaty, whereas the Global Compact would have no formally binding legal status.

We are returned again and again to the question of political will, in that any of these institutional or legal changes, however radical or modest, could occur only in conjunction with political and social movement necessary to create the conditions for change. Yet at the moment the political winds appear very much to be shifting away from such possibilities. 
A final alternative could therefore be considered, which would be to relinquish the notion of liberalized migration, as a feature of a global liberalization project which has proven now to have reached its political limits, and to correct the asymmetry problem not by calling for labor migration to keep up with liberalization in goods and capital, but rather by calling for a return across the board to a more modulated and more restricted market ideal. The "embedded liberalism" of the Keynesian era is often held up as the exemplar of an era featuring more socially desirable policy space for national governments to tailor access to their markets in keeping with their own economic and social objectives, including a relatively robust labor regime. It is worth pointing out that this was precisely the same era in which labor immigration into the US was much lower than the decades either beforehand or afterwards.

The question then arises: for those of us progressives who would support more policy space and more restrictiveness or protectiveness for states when it comes to market access for goods and capital, are we comfortable with the same approach when it comes to people? Or do people exert moral and social claims that might justify an asymmetry pointing in the opposite direction, one based not on economics but on ethics?

The case for open borders ultimately rests on a claim to universal equality. Given the disparity of wealth between the global North and South, and the role that migration can play in bridging that gap, opening the borders presents the best way to ensure that, contrary to the status quo, one's destiny is not predetermined by the place of one's birth. For those concerned with global economic inequality, global poverty and global development, the case seems plain. 
This claim, of course, runs into an objection that it is inconsistent with the arrangement of the international community and the world order into sovereign states. The sovereigntist objection itself can draw on numerous sources of justification, including democratic theory, communitarianism, and simply positive law. According to the sovereigntist objection, regardless of its independent value, the normative claim to equality is bested by the on the other side: those of citizens of the global North to the citizenship benefits of the social contracts in which they have entered with their own governments (democratic theory); claims of cultural or historical singularity, in which national communities, including in the global North, have morally salient reasons to preserve those communities even at the cost of excluding others (communitarianism); and claims that the legal and doctrinal principle of sovereignty carries its own moral weight - the morality of law itself, of the moral imperative to comply with law, and of the historical pedigree behind that law (positivism).

These objections however, can be countered, each on their own grounds. From the perspective of democratic theory, if the theory of democratic representation holds that people who are affected by governmental policies should be represented in the processes by which they are made, then foreign nationals have a democratic right to be included in the social contract when it comes to hegemonic powers such as the United States, whose governments so determine the policies and practices of their own. ${ }^{58}$ From the perspective of communitarianism, the empirical reality of an interconnected and transnational world belies the claims to cultural purity made by communitarians. ${ }^{59}$ One need look no further than the polyglot roots of the United States to see that this is true, or to the history of outward expansion of the global North to the global South. This 
last point also speaks to the objection from positive law. The claims to the sanctity of the sovereign territoriality are belied by a long and deep history of intervention by the global North in the political processes of the global South. ${ }^{60}$

At the same time, the case for open borders should be subject to all of the caveats and restraints that we would attach to other forms of market-opening policy when implemented by economic regulators. The process of liberalization would ideally be relatively gradual, and attended by measures to account for and compensate those displaced by the process. In sum, the asymmetry in the international economic order, between "open markets" and "closed borders" should be corrected, not by a retreat into nationalism, but by a movement of the international economic order to more closely approximate the progressive goals of equity and equality.

\footnotetext{
${ }^{1}$ Professor of Law, Cornell Law School.

${ }^{2}$ For a discussion of the phenomenon of "reterritorialization," see Chantal Thomas, "Trade and Development in an Era of Multipolarity and Reterritorialization," Yale Journal of International Law Online Symposium.

${ }^{3}$ Chantal Thomas, Disorderly Borders: How International Law Shapes Irregular Migration (London: Oxford University Press, forthcoming).

${ }^{4}$ Preamble to the General Agreement of Tariffs and Trade, now part of the World Trade Organization.

${ }^{5}$ I associate this terminology with Peter Andreas, "U.S.-Mexico: Open Markets, Closed Border," Foreign Policy 103 (Summer, 1996): 51-69.

${ }^{6}$ Howard F. Chang, "Migration as International Trade: The Economic Gains from the Liberalized Movement of Labor," UCLA Journal of International Law and Foreign Affairs 3 (1998): 371-414; Sungjoon Cho, "Development by Moving People: Unearthing the Development Potential of a GATS Visa," in Developing Countries in the WTO Legal System, 2009, 457-74; Joel P. Trachtman, The International Law of Economic Migration: Toward the Fourth Freedom (Kalamazoo, Mich: W.E. Upjohn Institute, 2009).

${ }^{7}$ Dani Rodrik, "It's Time to Think for Yourself on Free Trade," Foreign Policy, Jan 27, 2017.

${ }^{8}$ See Branco Milanovic, "Global Income Inequality in Numbers: in History and Now," Global Policy 4, no 3 (2013): 198-208 (204).
} 
9 Many authors, myself included, have pointed out that there is a strong argument that irregular migration can be understood as an intended, rather than unintended consequence, of economic liberalization policies. Undocumented workers provide a source of highly pliable and exploitable labor, and in that sense may well be both desired and sought by employers. Certainly this vulnerability to exploitation holds true whether the presence of these workers was intended or not.

${ }^{10}$ Kevin Johnson has provided an extensive discussion of the political debate surrounding the passage of NAFTA in the United States, and how proponents of NAFTA steered controversy around illegal immigration to shore up support for, and counter opposition to, NAFTA's implementation, by arguing that NAFTA would reduce illegal immigration by boosting economic growth in Mexico. Kevin R. Johnson, "Free Trade and Closed Borders: NAFTA and Mexican Immigration to the United States," Immigration \& Nationality Law Review 16 (19941995): 465-506 (489 \& n.92).

${ }^{11}$ Eli F. Heckscher and Bertil Ohlin, Heckscher-Ohlin Trade Theory, trans. and ed. Harry Flam and M. June Flanders (Cambridge, Mass.: MIT Press, 1991).

12 "Presidential Address: Clinton Urges Passage Of Free-Trade Pact." In CQ Almanac 1993, 49th ed., 46-D-47-D. Washington, DC: Congressional Quarterly, 1994. http://library.cqpress.com/cqalmanac/cqal93-844-25162-1104274.

${ }^{13}$ For a discussion of this literature, see Patricio Aroca and William F. Maloney, "Migration, Trade, and Foreign Direct Investment in Mexico," World Bank Economic Review 19, no. 3 (2005): 449-72 (449 \& n.1).

14 Assaf Razin and Efraim Sadka, "International Migration and International Trade," National Bureau of Economic Research, NBER Working Paper No. 4230 (Dec. 1992): 1-44 (19-25).

15 James Sterngold, Nafta Trade-Off: Some Jobs Lost, Others Gained, N.Y. Times, October 9, 1995, at A1.

16 Ibid.

${ }^{17}$ Ibid.

${ }^{18}$ Mark Weisbrot, Stephan Lefebvre, and Joseph Sammut, "Did NAFTA Help Mexico? An Assessment after 20 Years" (Center for Economic Policy Research, Washington, D.C., February 2014): 2 .

${ }^{19}$ Ibid. (citing the total number of Mexican migrants in the US as 9.4 million in 2000 and 12.6 in 2009 when migration peaked); Pew Research Center (Washington DC), Nov 2015, "More Mexicans Leaving than coming to the US," at 12 (citing 4.5 unauthorized migrants in 2000, and 6.9 in 2009).

${ }^{20}$ Pew Research Center (Washington DC), Nov 2015, "More Mexicans Leaving than coming to the US," at 7 (Figure 2).

${ }^{21}$ Pew 2015 at 12.

22 Francisco Meré, Rural Migration in Mexico (2007), at p.5 (reporting a 200\% increase in migration from rural Mexico to the US between 1994 and 2000).

${ }^{23}$ John J. Audley, Demetrios G. Papademetriou, Sandra Polaski and Scott Vaughan, NAFTA's Promise and Reality: Lessons from Mexico for the Hemisphere (Carnegie Endowment for International Peace, 2004), at 53.

${ }^{24}$ M. Angeles Villarreal and Ian F. Fergusson, "NAFTA at 20: Overview and Trade Effects" (Congressional Research Service, February 21, 2013) at 11. 
${ }^{25}$ The US Gross Domestic Product increased from $\$ 6.879$ trillion in 1993 to $\$ 16.155$ trillion in 2012 (US current dollars), an increase of 234\%. World Bank Development Data (available at data.worldbank.org).

${ }^{26}$ M. Angeles Villarreal and Ian F. Fergusson, "NAFTA at 20: Overview and Trade Effects" (Congressional Research Service, February 21, 2013), supra, at 1.

${ }^{27}$ Glenn Kessler, The strange tale about why Bill Clinton said NAFTA would create 1 million jobs, Washington Post, September 21, 2018.

${ }^{28}$ Gary Hufbauer and Jeffrey J. Schott, NAFTA: An Assessment (Washington DC: Institute for International Economics, 1993).

${ }^{29}$ M. Angeles Villarreal and Ian F. Fergusson, "NAFTA at 20: Overview and Trade Effects" (Congressional Research Service, February 21, 2013), supra, at 13.

${ }^{30}$ Ibid.

${ }^{31}$ Robert E. Scott, "Heading South: U.S.-Mexico trade and job displacement after NAFTA" (Economic Policy Institute, 2011), at 7.

${ }^{32} \mathrm{~J}$. Bradford Delong, NAFTA and other trade deals have not gutted American manufacturing period (Vox Magazine, January 2017) ("Before NAFTA was signed, we were already fivesevenths of the way from July 1953 to our present state in terms of losing manufacturing jobs. We were three-fifths of the way from January 1971 to our present state").

${ }^{33}$ Adams Nager, "Trade vs. Productivity: What Caused U.S. Manufacturing's Decline and How to Revive It" (Information Technology \& Innovation Foundation, 2017), at 8, 13; David H. Autor, David Dorn and Gordon H. Hanson, "Untangling Trade and Technology: Evidence from Local Labor Markets," The Economic Journal, 125 (May), 621-646.

${ }^{34}$ M. Angeles Villarreal and Ian F. Fergusson, "NAFTA at 20: Overview and Trade Effects" (Congressional Research Service, February 21, 2013), supra, at 14.

${ }^{35}$ Mark Weisbrot, Stephan Lefebvre, and Joseph Sammut, "Did NAFTA Help Mexico? An Assessment After 20 Years" (Center for Economic Policy Research, 2013), at 4.

${ }^{36}$ John J. Audley, Demetrios G. Papademetriou, Sandra Polaski and Scott Vaughan, NAFTA's Promise and Reality: Lessons from Mexico for the Hemisphere (Carnegie Endowment for International Peace, 2004), at 6.

${ }^{37}$ John J. Audley, Demetrios G. Papademetriou, Sandra Polaski and Scott Vaughan, NAFTA's Promise and Reality: Lessons from Mexico for the Hemisphere (Carnegie Endowment for International Peace, 2004), at 16.

${ }^{38}$ Ibid.

${ }^{39}$ I am grateful to Greg Shaffer for organizing a workshop in February 2017 in which I was able to present this research and discuss at length the standard trade economics view with noted trade lawyers and economists. Reconceiving Trade Agreements for Social Inclusion, UC Irvine School of Law, February 9-10, 2018.

${ }^{40}$ Pew 2015 at 7.

${ }^{41}$ Polaski Report at 2.

${ }^{42}$ UN DESA, Pop DIv.

${ }^{43}$ OECD Stats.

${ }^{44}$ USITC, The Impact of Trade Agreements, publication 3621 (2003).

${ }^{45}$ Polaski report at 4.

${ }^{46}$ Polaski report at 3 .

${ }^{47}$ Francisco Meré, Rural Migration in Mexico (2007), at p.5. 
${ }^{48}$ Fernando Lozano Ascencio, "Migration Strategies in Urban Contexts: Labor Migration from Mexico City to the United States," Migraciones internacionales 2, no. 3 (2004): 1-12.

${ }^{49}$ Fernando Lozano Ascencio, "Migration Strategies in Urban Contexts: Labor Migration from Mexico City to the United States," Migraciones internacionales 2, no. 3 (2004): 1-12.

${ }^{50}$ Jorge Durand, Douglas S. Massey, and Rene Zenteno.. "Mexican Immigration to the United States: Continuities and Changes," Latin American Research Review 36 (2001):107-27.

${ }^{51}$ Enrique Perez-Campuzano, Guillermo Castillo Ramirez, and Mateo Carlos Galindo Perez, Internal Migration in Mexico: Consolidation of Urban-Urban Mobility, 2000-2015. Growth and Change, vol. 49, no. 1, 233-240 (231).

${ }^{52}$ Fernando Lozano Ascencio, "Migration Strategies in Urban Contexts: Labor Migration from Mexico City to the United States," Migraciones internacionales 2, no. 3 (2004) at 5-6.

${ }^{53}$ Fernando Lozano Ascencio, "Migration Strategies in Urban Contexts: Labor Migration from Mexico City to the United States," Migraciones internacionales 2, no. 3 (2004) at 5-6.

${ }^{54}$ Elizabeth Fussell, "Sources of Mexico's Migration Stream: Rural, Urban, and Border Migrants to the United States," Social Forces 82, no. 3 (2004): 937-967 (938).

${ }^{55}$ Elizabeth Fussell, "Sources of Mexico's Migration Stream: Rural, Urban, and Border Migrants to the United States," Social Forces 82, no. 3 (2004): 937-967.

${ }^{56}$ Nina Glick Schiller, Linda Basch, and Christina Szanton-Blank, "From Immigrants to Transmigrants: Theorizing Transnational Migration," in Ludger Pries (ed.), Migration and Transnational Social Spaces, Ashgate, Aldershot England, 1999, pp. 73-105 (73).

${ }^{57}$ I say putative in an allusion to a more sinister reading of the political motivation which is that the production of unauthorized migration is an intended and desirable outcome for powerful interests who seek to undermine the bargaining power of available workforces.

${ }^{58}$ Arash Abizadeh, "Democratic Theory and Border Coercion: No Right to Unilaterally Control Your Own Borders." Political Theory 36, no. 1 (2008): 37-65.

${ }^{59}$ Kwame Anthony Appiah, Cosmopolitanism: Ethics in a World of Strangers. W. W. Norton \& Company, 2006.

${ }^{60}$ For a terrific discussion of these points, see Tendayi Achiume, Migration as Decolonization, forthcoming in the Stanford Law Review. For an extensive review of the political and legal theory implicated by migration and sovereignty, see Chantal Thomas, What Does the Emerging International Law of Migration Mean for Sovereignty? Melbourne Journal of International Law 14: $393-450$. 